\title{
Individual Creative Potential, Its Development and Fostering in Higher Education
}

\section{E. G. Kalyuzhnaya}

Ural Federal University, Yekaterinburg, Russia

\section{Abstract}

In this article, the author analyzes the ways in which institutions of higher education may foster the development of creative potential of the individuals. Modernization of the Russian education system increased the relevance of objective markers used to assess the quality of education received by the graduate students who are supposed to acquire relevant skills to further their professional creative activity. The purpose of article is to define the components of an individual's creative potential and the ways in which we can foster its development in universities.

Corresponding Author:

E. G. Kalyuzhnaya

Received: 22 November 2018 Accepted: 29 November 2018 Published: 23 December 2018

Publishing services provided by Knowledge $\mathrm{E}$

(c) E. G. Kalyuzhnaya. This article is distributed under the terms of the Creative Commons

Attribution License, which permits unrestricted use and redistribution provided that the original author and source are credited.

Selection and Peer-review under the responsibility of the Facets of Culture in the Age of Social Transition Conference Committee.
Keywords: creative potential, personal qualities, competence, culture, education, pedagogical technologies

\section{Introduction}

The system of higher education is an important social whose task is to transit cultural values as part of professional education. Colleges and universities train professionals capable of flexible adaptation in a changing society and of the creative innovative activity. Values, content, mechanisms and the corresponding standards used in the development of the educational process have always been determined by the dominant ideology of society and the resulting cultural dominant [8].

Modern world demands a certain type of the personality: aligned with the values of self-development, innovation and creativity and capable of creating socially significant products in their own professional activity. As a result, we see that personality development becomes the focus of education, and education, as a cultural institute, influences the development of personality, becomes instrumental in the development of its creative potential. This personality-centered approach, in turn, forms an axis of the educational process in higher education and establishes a cultural dominant that defines possible educational practices fostering the development of creative potential of the personality by addressing both its consciousness (value attitudes) and its practical actions. 
The issues of creative potential development within the educational framework take central stage in those specialties where creativity is vitally important and where students have not only to master their core curriculum but also to develop their creative imagination and aesthetic taste, to understand the underlying logic of creativity and to prepare to use these skills when faced with the unconventional professional tasks.

Modernization of the Russian education system increased the relevance of objective markers used to assess the quality of education received by the graduate students who are supposed to acquire relevant skills to further their professional creative activity. In this article we define what are the components of the individual's creative potential and how we can foster the development of this potential in universities.

\section{Materials and Methods}

The source of creativity and innovative personal behavior is the "tense opportunity" [7] and an ability to realize the creative potential. Potential (from Latin. potentio - force) is defined as existing set of capabilities, a source or a tool that an individual can employ in achieving a concrete goal. Creativity is defined as acting in such a way that something new emerges as a result of such activity; something capable of "improving existence in general" [10]. Creativity generates existing value-meanings and discover the new ones obtaining non-evident (uncommon) result and detecting non-standard solutions. Creativity is also understood as a self-actualization of an individual's identity. Creativity is traditionally believed to be a unity of process and result. Creative process combines logical and intuitive, conscious and unconscious components; in this process traditional cognitive abilities (perception, memory, representations, etc.) are creatively orientated (we experience not just a process of thinking or imagination, but creative thinking, creative imagination). Creativity as a product is distinguished by such characteristics as a combination of material and spiritual expression, novelty, originality.

When we try to determination a creative potential of the individual, we assume the existence of certain qualities that such an individual should possess, as a subject practical activity, as a producer of knowledge about the world, and as a self-aware initiator of his/her own object-oriented actions.

When analyzing actions of individuals in modern society, A.N. II'yin has defined several properties of the modern subject: integrity ('I'-integrity, world-view), autonomy (self-determination) and awareness (creativity and reflection) [6]. Researchers of creativity describe the following characteristics of the creative individual: creative 
activity [2]; motivation to act creatively, creativity is perceived as valuable [5]; 'emotional creativity' - that is, an ability to experience deep emotions and to understand these emotional reactions and states thus indicating a highly individual perception of events [13]; creative perception of the world and its imaginative representation using the language of art ('the artist's heart is in every object he creates') [3]; the creative uniqueness which displayed both in the process and in the results of creative activity [4].

Action-oriented approach describes the individual's creative potential as a personal resource, which, under the favorable conditions can become the basis of innovative creative behavior, fostering both personal development and the creation of new socially important products of material and non-material culture.

\section{Results}

Creative potential includes, first and foremost, an individual's personal qualities: creativity, reflexivity, emotional intelligence, intuition, personal motivation and value attitudes regarding professional activity. Secondly, there are certain competences that are the components of individual potential: some general, other professional. These competencies ensure the professionalism in chosen area. General competencies include instrumental, interpersonal and systemic competencies.

Instrumental competences require cognitive abilities (abilities to understand and use the ideas); methodological abilities (abilities to understand and manage the environment, to organize time, to build a decision-making strategy and problem solutions); technological abilities (computer skills and abilities to manage information management and technology in general); linguistic abilities (communicative competences).

Interpersonal competences are tied to the individual abilities, emotional and interpersonal expressiveness, critical assessment and self-criticism, as well as social interaction skills, group cooperation and an ability to carry social and ethical obligations.

Systemic competences rely on a combination of understanding, perceptivity and knowledge, which allows an individual to perceive the parts and the whole in their interconnection and unity. These abilities include an ability to design changes to improve the existing systems and to development the new ones. Professional competences include knowledge and skills specific for a concrete activity; professional motivation; professional-oriented attitudes regarding the chosen specialty. These competences are realized as an awareness of prospective self-realization and selfexpression in the professional sphere. 


\section{Discussion}

Practical implementation of the teaching and educational process that provides conditions required to foster an individual's creative potential within the framework of higher education means that we have to carefully justify our choice of approaches, methods, tools and technologies. The resulting framework in pedagogy is usually described by the closely connected concepts of 'teaching technology', 'educational technology', 'pedagogical technology'. Our analysis of the classifications of pedagogical technologies existing in research literature $[1,11]$ helped to define some of the prospective pedagogical technologies useful for creating educational conditions for effective fostering and development of the students' creative potential.

The personalized teaching approach is based on the co-creative educational environment, which should foster self-improving personality possessing creative attitude towards his/her future profession, as well as motivation to progress in the chosen professional area. The use of such personalized approach, applied to the development of individual creative potential, strives to foster creative thinking as a professional and creative component of the future personality and to acquire the basics of professional experience.

Collaborative training is aimed at the development of individual social competences while maintaining intellectual autonomy. The feeling of participation in joint activity fosters individual responsibility and cultivates the culture of supportive interdependence among the team members. Working together to achieve successful results develops assertiveness, emotional stability, leadership potential, as well as social skills required in any field of professional activity: ability to find creative solutions, establish dialogue and manage conflicts.

One of methods of team work is the method of 'brainstorming': a process of collectively solving an intellectual task by proposing individual solutions, often preliminary and even fantastical, which are subsequently discussed together [12]. This method aims to stimulate creative activity of each individual participant and to develop intellectual skills within the context of teamwork and in a situation limited in space and time ('here and now').

The students' personal qualities and the development of their individual creative potential are not pre-programmed by the official standards of higher education they are a part of the culture in general, partly inheriting the tradition that is formed within the system of secondary education. However, students do develop their individual creative potential during their studies (especially in humanities), when they 
acquire knowledge and understanding of the cultural past and develop their own value attitudes, while interiorizing the past culture (for example, by reflecting on the cultural past, an individual can analyze contemporary sociocultural processes). In practice, teaching humanities, for example, presupposes the development of more sophisticated understanding of the world. The goal of higher education - especially humanities - is to 'produce' more complex individuals by teaching them a non-linear tridimensional understanding of the world and an ability to grasp complex reality.

This task can be easily incorporated into the framework of higher education. Transmission of cultural values is possible through the transmission of culture itself, as well as past and present cultural artifacts in their complex interaction; by exploring the history of changing world-pictures and cultural ideals. This process fosters the development of students' creative potential: their abilities to correlate different value systems and world-views, thereby understanding the complexity of the world; their awareness of the importance of common humanistic human values. In this respect, higher education becomes an institute and a mechanism of cultural reproduction in society, establishing conditions the fostering students' development and their personal self-realization; for the flowering of their creative individual potential.

\section{References}

[1] Bespal'ko, V. P. (1989). Slagaemye pedagogicheskoy tekhnologii. Moscow: Pedagogika.

[2] Bogoyavlenskaya, D. B. (2002). Psikhologiya tvorcheskikh sposobnostey. Moscow: Akademiya.

[3] Boreev, Yu. B. (1997). Estetika, vol. 1. Smolensk: Rusich.

[4] Varlamova, E. P. (2002). Psikhologiya tvorcheskoy unikal'nosti cheloveka: refleksivnogumanisticheskiy podkhod. Moscow: Institute of Psychology, Russian Academy of Sciences.

[5] Druzhinin, V. N. (2005). Tvorchestvo: priroda i razvitie. Psikhologiya. Zhurnal Vysshey shkoly ekonomiki, vol. 2, no. 3, pp. 91-107.

[6] Il'in, A. N. (2010). Sub"ekt v massovoy kul'ture sovremennogo obshchestva potrebleniya (na materiale kitch-kul'tury). Omsk: Amfora.

[7] Klochko, V. E. (2009). Innovatsionnyy potentsial lichnosti: sistemnoantropologicheskiy kontekst, in Proceedings of Tomsk State University, vol. 325. Retrieved from https://cyberleninka.ru/article/n/innovatsionnyy-potentsiallichnosti-sistemno-antropologicheskiy-kontekst (accessed on March 04, 2018). 
[8] Ogurtsov, A. P. (2001). Postmodernistskiy obraz cheloveka i pedagogika. Chelovek, vol. 3, p. 9.

[9] (2009). Psikhologiya innovatsionnoy deyatel'nosti: tezaurus (slovar', okhvatyvayushchiy spetsifiku professional'noy leksiki). Tomsk: TGU.

[10] Sagatovskiy, V. N. (2012). Aksiologiya tvorchestva. Nauka. Iskusstvo. Kul'tura, vol. 1, pp. 58-63.

[11] Selevko, G. K. (2006). Entsiklopediya obrazovatel'nykh tekhnologiy, vol. 1. Moscow: NII shkol'nykh tekhnologiy.

[12] Serikov, V. V. (1994). Lichnostnyy podkhod v obrazovanii: kontseptsiya i tekhnologiya. Volgograd: Peremena.

[13] Yakovleva, E. L. (1996). Razvitie tvorcheskogo potentsiala lichnosti kak tsel' obrazovaniya. Mir psikhologii, vol. 2, pp. 145-151. 